\title{
Potential Emergence of Plasmodium Resistance to Artemisinin Induced by the Use of Artemisia annua for Malaria and COVID-19 Prevention in Sub-African Region
}

\author{
Essoham Ataba ${ }^{1,2}$ (D) Ameyo M. Dorkenoo ${ }^{3} \cdot$ Christèle Tchopba Nguepou $^{1} \cdot$ Tchaa Bakai $^{2} \cdot$ Tchassama Tchadjobo $^{2}$. \\ Komla Dovenè Kadzahlo ${ }^{2} \cdot$ Kossi Yakpa ${ }^{2} \cdot$ Tinah Atcha-Oubou $^{2}$
}

Received: 28 June 2021 / Accepted: 26 October 2021 / Published online: 19 November 2021

(c) The Author(s), under exclusive licence to Witold Stefański Institute of Parasitology, Polish Academy of Sciences 2021, corrected publication 2021

\begin{abstract}
Plasmodium resistance to antimalarial drugs is an obstacle to the elimination of malaria in endemic areas. This situation is particularly dramatic for Africa, which accounts for nearly $92 \%$ of malaria cases worldwide. Drug pressure has been identified as a key factor in the emergence of antimalarial drug resistance. Indeed, this pressure is favoured by several factors, including the use of counterfeit forms of antimalarials, inadequate prescription controls, poor adherence to treatment regimens, dosing errors, and the increasing use of other forms of unapproved antimalarials. This resistance has led to the replacement of chloroquine (CQ) by artemisinin-based combination therapies (ACTs) which are likely to become ineffective in the coming years due to the uncontrolled use of Artemisia annua in the sub-Saharan African region for malaria prevention and COVID19. The use of Artemisia annua for the prevention of malaria and COVID-19 could be an important factor in the emergence of resistance to Artemisinin-based combination therapies.
\end{abstract}

Keywords COVID-19 $\cdot$ Malaria $\cdot$ Resistance $\cdot$ Artemisinin $\cdot$ Plasmodium falciparum

\section{Background}

Malaria is caused by parasites of the Plasmodium species and it is a global public health burden. In 2019, WHO reported 228 million malaria cases and 405,000 deaths worldwide, with a predominance in sub-Saharan Africa [1]. In December 2019, new pneumonia called coronavirus disease 2019 (COVID-19), caused by severe acute respiratory

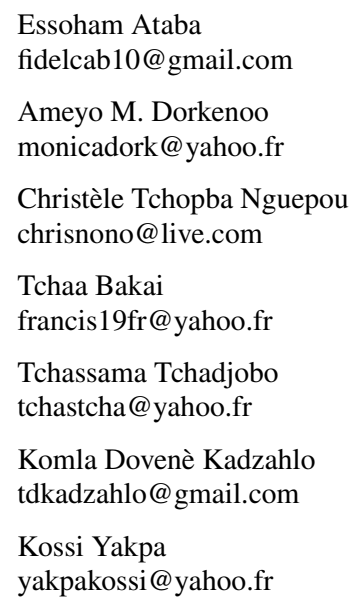

syndrome coronavirus 2 (SARS-CoV-2), with some clinical features similar to malaria such as fever, was reported in Wuhan, China [2]. COVID-19 rapidly evolved into a global pandemic, declared by the World Health Organization (WHO) on March 11, 2020, as a Public Health Emergency International Concern (PHEIC) [3]. At September 30, 2021, there were more than $234,390,731$ confirmed cases in 223 countries and deaths exceeded 4,792,848 [4].

Tinah Atcha-Oubou

atchaoubou@yahoo.fr

1 Ecole Supérieure des Techniques Biologiques et Alimentaires (ESTBA)/Unité de Recherche en Immunologie et Immunomodulation (UR2IM), Université de Lomé, Boulevard Eyadema, 01BP 1515 Lomé, Togo

2 Programme National de Lutte Contre le Paludisme, Ministère de la Santé de l'Hygiène Publique et de l'Accès Universel Aux Soins, Quartier Administratif, 01BP 518 Lomé, Togo

3 Faculté des Sciences de la Santé, Université de Lomé, Boulevard Eyadema, 01BP 1515 Lomé, Togo 
The use of plants for health care is a matter of culture and tradition in Africa [5-9]. It should be noted that for primary health needs, a large part of the African population resorts to traditional medicine, whose remedies mostly come from plant origin $[6,10]$. The preference for these remedies is due to their accessibility and their low cost [11, 12]. This use has increased with the emergence of COVID-19. Thus, to prevent this disease, people deliberately use extracts of Artemisia annua (a plant containing artemisinin), which is also used by people to prevent malaria [13, 14]. Malaria is endemic in tropical and subtropical low-income countries, and the inadequate use of antimalarial drugs, especially artemisinin, for malaria prevention and in the context of COVID-19 could lead to an increase of Plasmodium resistance to antimalarial drugs, including artemisinin and its derivatives, thus compromising their efficacy. Therefore, such resistance would affect malaria control in these regions and jeopardize efforts to eliminate malaria by 2030 [15]. Our review focused on the selection factors of Plasmodium resistance to antimalarial drugs and the risk of emergence of resistance to artemisinin and its derivatives due to the empirical use of Artemisia annua in one part, and in another part the need to monitor regularly the efficacy of antimalarial drugs to achieve the goal of malaria elimination in Africa on time.

\section{Selection Factors for Plasmodium Resistance to Antimalarial Drugs}

Drug pressure has been identified as a key factor in the emergence of antimalarial drug resistance [16]. Antimalarial drug resistance must be considered in two parts: on the one hand, the initial genetic event that produces the resistant mutant, and on the other hand, the subsequent selection process in which the survival advantage in the presence of the antimalarial drug leads to the preferential transmission and spread of resistance [17]. Indeed, the evolution of antimalarial drug resistance is facilitated by several factors, including the use of counterfeit forms of antimalarial drugs, inadequate controls on prescribing, poor adherence to treatment regimens, incorrect dosing, and the increasing use of other forms of unlicensed antimalarial drugs [18, 19]. This last factor has attracted more attention from WHO in recent years with the deliberate use of Artemisia annua extracts for malaria prevention and COVID-19 [20-23].

About artemisinin, while this plant is currently cultivated in various regions of African countries, studies have revealed that there is a diversity of Artemisia annua species, and for the same species, the artemisinin content can vary from one region to another depending on the composition of the soils on which these plants are grown [24, 25]. Thus, these Artemisia extracts are likely to exert undesirable drug pressure over a long period of time once their concentrations fall below the critical threshold and may select for resistant parasites [26].

In Africa, the resistance to CQ had led to its replacement by artemisinin-based combination therapies (ACTs) [27-29]. This resistance has appeared in Southeast Asia, for all classes of antimalarial drugs and recently for artemisinin, the main component of current antimalarial drugs [16, 30, 31] with an increase in markers of this resistance in African countries [30]. Not only the effects of resistance on morbidity and mortality are generally underestimated [32, 33], but it is also an obstacle to malaria elimination [34, 35].

\section{Resistance of Plasmodium to Artemisinin and Its Derivatives}

Artemisinin has been discovered since the early 1970 s by Dr. Youyou Tu, the 2015 Nobel Laureate, as an effective drug for the treatment of malaria [36]. Following WHO recommendations, artemisinin-based combination therapies (ACTs) are used for malaria treatment in Africa, because fast-acting artemisinin can immediately reduce parasitaemia, allowing the remaining parasites to be eliminated with a long-acting partner drug [37]. Although recent studies have confirmed the existence of artemisinin resistance in $P$. falciparum [38], artemisinin and its derivatives have nonetheless made progress in the treatment of malaria and have made quinolones as a secondary treatment option in most countries of the world [38, 39].

Since 2014, mutations in the "helix" region of a $P$. falciparum Kelch protein (encoded by the kelch13 gene) have been identified as molecular markers of artemisinin resistance based on their association with the slow clearance phenotype [40].

In Asia, $36.5 \%$ of K13 mutations were distributed in two areas, one in Cambodia, Vietnam and Laos, and the other in western Thailand, Myanmar and China [41].

In Africa, non-synonymous mutations are still rare and very diverse. Non-synonymous K13 mutations have been reported in Angola, Burkina Faso, Cameroon, Central African Republic, Comoros, Congo, Ivory Coast, Democratic Republic of Congo, Equatorial Guinea, Ethiopia, Gabon, Gambia, Kenya, Liberia, Madagascar, Malawi, Mali, Mozambique, Niger, Nigeria, Rwanda, Senegal, Sierra Leone, Togo, Uganda and Zambia [42]. However, a recent study in Uganda found an association between K13 mutations and delayed parasite clearance in subjects treated with artesunate, a soluble arteminisin derivative [30].

In Togo, $1.8 \%$ of K13 mutations were identified in three sentinel sites monitoring antimalarial efficacy in 2013 [40]. Although $K 13$ helix mutations associated with artemisinin resistance have been found in Tanzania and Uganda [30, 41], 
there is no evidence of emerging resistance to artemisinin and its derivatives associated with K13 mutations in Togo in particular [40].

Furthermore, immunity may also play an important role in the emergence and transmission potential of artemisininresistant parasites [43]. Most malaria infections are genetically diverse [44-47], and this diversity increases in areas of high transmission where hosts experience frequent and overlapping infections [48-51]. In a multi-infected host, different lineages compete for the same resources while being subject to specific and non-specific immune regulation. When drug-resistant and drug-sensitive parasites are present in the same host, the sensitive lineages can suppress the growth and transmission of the resistant lineages [52-54]. However, reduced malaria transmission decreases naturally acquired immunity, which may influence the emergence of artemisinin-resistant phenotypes and genotypes of Plasmodium falciparum over time [55]. It is important to understand how changing transmission and immunity could impact the emergence of artemisinin resistance, especially as increased malaria control and elimination activities may improve the immunological conditions for the expansion of artemisininresistant $P$. falciparum [56].

To ensure that the current COVID-19 pandemic does not result in a major upsurge in malaria cases, derailing subSaharan Africa elimination efforts, it is critical that the recommended malaria case management practices and procedures are closely monitored [57].

\section{Use of Domestic Artemisinin for the Treatment of COVID-19}

The effective antimalarial drugs recommended by the WHO are made from artemisinin isolated from Artemisia aпnиа [58]. Thus, populations especially in malaria-endemic areas empirically use infusions of Artemisia апnиa leaves to prevent or treat malaria [59]. While its active ingredient (artemisinin) content is dependent on geo-climatic factors and season [60], it is currently planted in several countries for domestic use against malaria [61].

With the emergence of COVID-19 pandemic, many populations have illegally adopted Artemisia annua for the prevention and treatment of COVID-19, despite WHO calls against its use without proper scientific approval [20-23]. For example, Madagascar has used a tonic (Covid Organic) from Artemisia аппиа as a potential remedy for COVID-19 [62]. Unfortunately, no studies to date have elucidated the interactions of artemisinin on the angiotensin-converting enzyme 2 (ACE2) receptor, which is known to be the critical cellular binding receptor for SARS-CoV-2 [63], although studies have demonstrated the anti-inflammatory potential of high-dose artesunate in the context of COVID-19 [64, 65].
This may partially justify the rejection of some institutions such as WHO to allow artemisinin as a cure for COVID-19 [23].

\section{Impact of Plasmodium Resistance to Antimalarial Drugs on the Achievement of the New Malaria Strategy Plan}

Remarkable advances in malaria control in recent years have been partially wiped out by the COVID-19 pandemic [66] Therefore, WHO recommends attention to malaria interventions while responding to the pandemic to avoid the unintended consequences of SARS-CoV-2 on malaria in Africa [3]. Although medicinal plants such as Artemisia annua are considered as possible treatments for COVID-19, its use has been discouraged by the WHO, due to lack of data on the efficacy of the extracts and lack of safety information [67-69]. In fact, its use could potentiate the development of resistance to ACTs, especially in Africa where the malaria burden remains the highest [1].

However, resistance has been shown to occur primarily during the ring stage of parasite development due to multiple forms of mutations in the Kelch PF3D7_1343700 (K13-propeller) helix domain on chromosome 13 [70]. Mutations in the K13-propeller lead to an increase in phosphatidylinositol-3-kinase (PfPI3K), which is required to mediate cell signalling and survival [71]. The latter leads to vesicle expansion that increases engagement in the unfolded protein response (UPR) [72]. Vesicle expansion (rather than increasing individual genetic determinants of UPR) effectively induces artemisinin resistance, presumably by promoting "proteostasis" (protein translation coupled with proper protein folding and vesicle remodelling) to mitigate artemisinin-induced proteinopathy (death due to abnormal overall protein toxicity) [73]. This may jeopardize malaria elimination plans in African countries and other malaria-prone regions, as artemisinin monotherapy and especially low-dose artemisinin monotherapy could lead to the spreading of the Kelch13-positive strains in Africa [74]. While resistance to most malaria drugs (amodiaquine, lumefantrine, mefloquine and sulfadoxine-pyrimethamine) has already been well demonstrated [74, 75], the uncontrolled use of artemisinin-based drugs could be a factor for the emergence of resistance in the coming years [76]. Following the pattern of CQ resistance, Plasmodium may become increasingly resistant to artemisinin in the coming years.

Furthermore, although control strategies for COVID-19 have been significantly improved by vaccination [77, 78], malaria control strategies are disrupted, particularly in lowresource settings where clinical facilities are extremely limited [66]. Thus, controlling COVID-19 is a global challenge. Malaria elimination would be effective if efforts against 
COVID-19 were also engaged in the fight against malaria, which causes more than 400,000 deaths per year in Africa, with children being the most affected [1, 79-81]. Given that the burden of malaria is highest in low-income tropical countries that have little capacity to fund malaria control and elimination programmes, malaria control in these regions is likely to be hampered in a few years by the spreading of the Kelch13-positive strains. To verify this hypothesis and to trace this potential risk, it would be good to set up regular monitoring sites in all African countries to detect in time any suspicious increase of molecular markers or its appearance, so as to be able to act quickly to prevent its propagation to other regions of the world.

\section{Conclusion}

Plasmodium resistance to antimalarial drugs is an obstacle in the fight against malaria. The resistance to ACTs especially could be potentiated by the use of Artemisia annua for the prevention and treatment of malaria and COVID-19. Although COVID-19 has a collateral impact in Africa, this pandemic could be an important factor in the emergence of TCA resistance. Therefore, more concerted efforts are needed to defeat these two diseases.

Author Contributions EA, AMD and CTN contributed to the design of the study and analysed the research data. TB, TT, KDK, KY and TA provided additional articles related to the topic. EA, AMD and CTN wrote the review which was then read and approved by all the other authors.

\section{Declarations}

Conflict of Interest The authors declare that they have no competing interests.

\section{References}

1. WHO (2019) World Malaria Report 2019. World Health Organization. https://www.who.int/malaria/publications/world-malar ia-report-2019/en/. Accessed April 21, 2021

2. Hoffmann M, Kleine-Weber H, Schroeder S, Kruger N, Herrler T, Erichsen S (2020) SARS-CoV-2 cell entry depends on ACE2 and TMPRSS 2 and is blocked by a clinically proven protease inhibitor. Cell 181:271-280. https://doi.org/10.1016/j.cell.2020.1002.1052

3. WHO (2020) Tailoring Malaria Interventions in the COVID-19 Response. Geneva: WHO. https://www.who.int/malaria/publi cations/atoz/tailoring-malaria-interventions-covid-19.pdf?ua= 11. Accessed May 15, 2021

4. Worldometer (2021) Reported Cases and Deaths by Country or Territory. https://www.worldometers.info/coronavirus/. Accessed September 30, 2021

5. Jeruto P, Lukhoba C, Ouma G, Otieno D, Mutai C (2008) An ethnobotanical study of medicinal plants used by the Nandi people in Kenya. J Ethnopharmacol 116(2):370-376. https://doi.org/10. 1016/j.jep.2007.11.1041

6. Tchacondo T, Karou SD, Batawila K, Agban A, Ouro-Bang'na K, Anani KT, Gbeassor M, de Souza C (2011) Herbal remedies and their adverse effects in Tem tribe traditional medicine in Togo. AJTCAM 8(1):45-60. https://doi.org/10.4314/ajtcam.v4318i4311. 60522

7. Abdullahi AA (2011) Trends and challenges of traditional medicine in Africa. AJTCAM 8(5):115-123. https://doi.org/10.4314/ ajtcam.v8i5S.5

8. Quiroz D, van Andel T (2018) The cultural importance of plants in Western African religions. Econ Bot 72(3):251-262. https:// doi.org/10.1007/s12231-018-9410-x

9. Towns AM, Mengue Eyi S, van Andel T (2014) Traditional medicine and childcare in Western Africa: mothers' knowledge, folk illnesses, and patterns of healthcare-seeking behavior. PLoS ONE 9(8):e105972. https://doi.org/10.1371/journal.pone.0105972

10. Karou SD, Tchacondo T, Ouattara L, Anani K, Savadogo A, Agbonon A, Attaia MB, de Souza C, Sakly M, Simpore J (2011) Antimicrobial, antiplasmodial, haemolytic and antioxidant activities of crude extracts from three selected Togolese medicinal plants. Asian Pac J Trop Med 4(10):808-813

11. Chali BU, Hasho A, Koricha NB (2021) Preference and practice of traditional medicine and associated factors in Jimma Town, Southwest Ethiopia. Evid Based Complement Alternat Med. https://doi. org/10.1155/2021/9962892

12. Welz AN, Emberger-Klein A, Menrad K (2018) Why people use herbal medicine: insights from a focus-group study in Germany. BMC Complement Altern Med 18(1):92. https://doi.org/10.1186/ s12906-018-2160-6

13. Nair MS, Huang Y, Fidock DA, Polyak SJ, Wagoner J, Towler MJ, Weathers PJ (2021) Artemisia annua L. extracts inhibit the in vitro replication of SARS-CoV-2 and two of its variants. BioRxiv 2008:425825

14. Septembre-Malaterre A, Lalarizo Rakoto M, Marodon C, Bedoui Y, Nakab J, Simon E, Hoarau L, Savriama S, Strasberg D, Guiraud $P$ et al (2020) Artemisia annua, a traditional plant brought to light. Int J Mol Sci 21(14):4986

15. WHO (2015) Global Technical Strategy for Malaria 2016-2030. http://apps.who.int/iris/bitstream/handle/10665/176712/97892 41564991_eng.pdf?sequence=9789241564991. Accessed April 21,2021

16. Stokes BH, Dhingra SK, Rubiano K, Mok S, Straimer J, Gnädig NF, Deni I, Schindler KA, Bath JR, Ward KE et al (2021) Plasmodium falciparum K13 mutations in Africa and Asia impact artemisinin resistance and parasite fitness. Elife 10:e66277

17. Day N, Pham T, Phan T, Dinh X, Pham P, Ly V, Tran T, Nguyen T, Bethell DB, Nguyan H (1996) Clearance kinetics of parasites and pigment-containing leukocytes in severe malaria. Blood 88(12):4694-4700 (PMID: 8977263)

18. Wernsdorfer WH (1991) The development and spread of drugresistant malaria. Parasitol Today 7(11):297-303. https://doi.org/ 10.1016/0169-4758(91)90262-m

19. Wernsdorfer WH (1994) Epidemiology of drug resistance in malaria. Acta Trop 56(2-3):143-156. https://doi.org/10.1016/ 0001-706x(94)90060-4

20. Cao R, Hu H, Li Y, Wang X, Xu M, Liu J, Zhang H, Yan Y, Zhao L, Li W et al (2020) Anti-SARS-CoV-2 potential of Artemisinins In Vitro. ACS Infect Dis 6(9):2524-2531

21. Gendrot M, Duflot I, Boxberger M, Delandre O, Jardot P, Le Bideau M, Andreani J, Fonta I, Mosnier J, Rolland C et al (2020) Antimalarial artemisinin-based combination therapies (ACT) and COVID-19 in Africa: in vitro inhibition of SARS-CoV-2 replication by mefloquine-artesunate. Int J Infect Dis 99:437-440

22. Li G, Yuan M, Li H, Deng C, Wang Q, Tang Y, Zhang H, Yu W, Xu Q, Zou Y et al (2020) Safety and efficacy of 
Artemisinin-Piperaquine for treatment of COVID-19: an openlabel, non-randomized, and controlled trial. Int J Antimicrob Agents. https://doi.org/10.1016/j.ijantimicag.2020.106216

23. Tang Y, Liu J, Zhang D, Xu Z, Ji J, Wen C (2020) Cytokine storm in COVID-19: the current evidence and treatment strategies. Front Immunol 11:1708. https://doi.org/10.3389/fimmu. 2020.01708

24 Wetzstein HY, Porter JA, Janick J, Ferreira JFS, Mutui TM (2018) Selection and clonal propagation of high Artemisinin Genotypes of Artemisia annua. Front Plant Sci. https://doi.org/10.3389/fpls. 2018.00358

25. Mannan A, Ahmed I, Arshad W, Asim MF, Qureshi RA, Hussain I, Mirza B (2010) Survey of artemisinin production by diverse Artemisia species in northern Pakistan. Malar J 9(1):310. https:// doi.org/10.1186/1475-2875-9-310

26. Watkins W, Mberu E, Winstanley P, Plowe C (1997) The efficacy of antifolate antimalarial combinations in Africa: a predictive model based on pharmacodynamic and pharmacokinetic analyses. J Parasitology Today 13(12):459-464

27. Mutabingwa T, Nzila A, Mberu E, Nduati E, Winstanley P, Hills E, Watkins W (2001) Chlorproguanil-dapsone for treatment of drug-resistant falciparum malaria in Tanzania. Lancet 358(9289):1218-1223

28. Roper C, Pearce R, Bredenkamp B, Gumede J, Drakeley C, Mosha F, Chandramohan D, Sharp B (2003) Antifolate antimalarial resistance in southeast Africa: a population-based analysis. Lancet 361(9364):1174-1181

29. Plowe CV, Kublin JG, Dzinjalamala FK, Kamwendo DS, Chimpeni P, Molyneux ME (2004) Taylor TE (2004) Sustained clinical efficacy of sulfadoxine-pyrimethamine for uncomplicated falciparum malaria in Malawi after 10 years as first line treatment: five year prospective study. BMJ 328(7439):545

30. Balikagala B, Fukuda N, Ikeda M, Katuro OT, Tachibana S-I, Yamauchi M, Opio W, Emoto S, Anywar DA, Kimura E et al (2021) Evidence of Artemisinin-resistant malaria in Africa. N Engl J Med 385(13):1163-1171. https://doi.org/10.1056/NEJMo a2101746

31 Rosenthal PJ (2021) Has artemisinin resistance emerged in Africa? Lancet Infect Dis 21(8):1056-1057. https://doi.org/10. 1016/S1473-3099(21)00168-7

32. Trape J-F, Pison G, Preziosi M-P, Enel C, du Loû AD, Delaunay V, Samb B, Lagarde E, Molez J-F, Simondon F (1998) Impact of chloroquine resistance on malaria mortality. Comptes Rendus de l'Académie des Sciences-Series III-Sciences de la Vie 321(8):689-697

33 White N (1999) Antimalarial drug resistance and combination chemotherapy. Philos Trans R Soc Lond B Biol Sc 354(1384):739-749. https://doi.org/10.1098/rstb.1999.0426

34. Bazie VB, Ouattara AK, Sagna T, Compaore TR, Soubeiga ST, Sorgho PA, Yonli AT, Simpore J (2020) Resistance of Plasmodium falciparum to Sulfadoxine-Pyrimethamine (Dhfr and Dhps) and Artemisinin and Its Derivatives (K13): A Major Challenge for Malaria Elimination in West Africa. J Biosci Med 8:82-95. https://doi.org/10.4236/jbm.2020.82007

35. Tang Y-Q, Ye Q, Huang H, Zheng W-Y (2020) An overview of available antimalarials: discovery, mode of action and drug resistance. J Curr Mol Med 20(8):583-592

36. Su X-Z, Miller LH (2015) The discovery of artemisinin and the Nobel Prize in physiology or medicine. Sci China Life Sci 58(11):1175-1179

37. Ashley EA, Stepniewska K, Lindegårdh N, McGready R, Annerberg A, Hutagalung R, Singtoroj T, Hla G, Brockman A, Proux $S$ et al (2007) Pharmacokinetic study of artemether-lumefantrine given once daily for the treatment of uncomplicated multidrugresistant $P$. falciparum malaria. Trop Med Int Health 12(2):201208. https://doi.org/10.1111/j.1365-3156.2006.01785.x
38 Tilley L, Straimer J, Gnädig NF, Ralph SA, Fidock DA (2016) Artemisinin action and resistance in Plasmodium falciparum. Trends Parasitol 32(9):682-696. https://doi.org/10.1016/j.pt.2016. 05.010

39. McIntosh HM, Olliaro P (2000) Artemisinin derivatives for treating severe malaria. Cochrane Database Syst Rev 1998(2):CD000527

40. Ariey F, Witkowski B, Amaratunga C, Beghain J, Langlois A-C, Khim N, Kim S, Duru V, Bouchier C, Ma L (2014) A molecular marker of artemisinin-resistant Plasmodium falciparum malaria. J Nature 505(7481):50-55. https://doi.org/10.1038/nature12876

41. Ménard D, Khim N, Beghain J, Adegnika AA, Shafiul-Alam M, Amodu O, Rahim-Awab G, Barnadas C, Berry A, Boum Y et al (2016) A worldwide Map of Plasmodium falciparum K13-propeller polymorphisms. N Engl J Med 374(25):2453-2464. https://doi. org/10.1056/NEJMoa1513137

42. WHO (2016) Artemisinin and artemisinin-based combination therapy resistance. Global Malaria Programme. http://apps.who. int/iris/bitstream/handle/10665/208820/WHO_HTM_GMP_ 202016.208825_eng.pdf? sequence $=208821$. Accessed May 18,2021

43. Ataide R, Ashley EA, Powell R, Chan J-A, Malloy MJ, O'Flaherty K, Takashima E, Langer C, Tsuboi T, Dondorp AM et al (2017) Host immunity to Plasmodium falciparum and the assessment of emerging artemisinin resistance in a multinational cohort. Proc Natl Acad Sci USA 114(13):3515-3520

44. Tanner M, Beck HP, Felger I, Smith T (1999) The epidemiology of multiple plasmodium falciparum infections. 1. General introduction. Trans R Soc Trop Med Hyg 93(Suppl 1):1-2. https://doi. org/10.1016/s0035-9203(1099)90319-x

45. Ae IE, ElGhazali G, A-Elgadir TM, Hamad AA, Babiker HA, Elbashir MI, Giha HA (2007) Allelic polymorphism of MSP2 gene in severe $\mathrm{P}$ falciparum malaria in an area of low and seasonal transmission. Parasitol Res 102(1):29-34

46. Babiker HA, Creasey AM, Fenton B, Bayoumi RA, Arnot DE, Walliker D (1991) Genetic diversity of Plasmodium falciparum in a village in eastern Sudan. 1. Diversity of enzymes, 2D-PAGE proteins and antigens. Trans R Soc Trop Med Hyg 85(5):572-577

47. Paul RE, Hackford I, Brockman A, Muller-Graf C, Price R, Luxemburger C, White NJ, Nosten F, Day KP (1998) Transmission intensity and Plasmodium falciparum diversity on the northwestern border of Thailand. Am J Trop Med Hyg 58(2):195-203

48 Babiker HA, Lines J, Hill WG, Walliker D (1997) Population structure of Plasmodium falciparum in villages with different malaria endemicity in east Africa. Am J Trop Med Hyg 56(2):141-147. https://doi.org/10.4269/ajtmh.1997.56.141

49. Arnot D (1998) Unstable malaria in Sudan: the influence of the dry season Clone multiplicity of Plasmodium falciparum infections in individuals exposed to variable levels of disease transmission. Trans R Soc Trop Med Hyg 92(6):580-585

50. Juliano JJ, Porter K, Mwapasa V, Sem R, Rogers WO, Ariey F, Wongsrichanalai C, Read A, Meshnick SR (2010) Exposing malaria in-host diversity and estimating population diversity by capture-recapture using massively parallel pyrosequencing. Procd Natl Acad Sci 107(46):20138-20143. https://doi.org/10.1073/ pnas. 1007068107

51. Mideo N, Bailey JA, Hathaway NJ, Ngasala B, Saunders DL, Lon C, Kharabora O, Jamnik A, Balasubramanian S, Björkman A et al (2016) A deep sequencing tool for partitioning clearance rates following antimalarial treatment in polyclonal infections. Evol Med Public Health 6(1):21-36. https://doi.org/10.1093/emph/eov1036

52. Wargo AR, Huijben S, de Roode JC, Shepherd J, Read AF (2007) Competitive release and facilitation of drug-resistant parasites after therapeutic chemotherapy in a rodent malaria model. Proc Natl Acad Sci USA 104(50):19914-19919. https://doi.org/10. 1073/pnas.0707766104 
53. de Roode JC, Helinski ME, Anwar MA, Read AF (2005) Dynamics of multiple infection and within-host competition in genetically diverse malaria infections. Am Nat 166(5):531-542. https:// doi.org/10.1086/491659

54. Bushman M, Morton L, Duah N, Quashie N, Abuaku B, Koram KA, Dimbu PR, Plucinski M, Gutman J, Lyaruu P et al (2016) Within-host competition and drug resistance in the human malaria parasite Plasmodium falciparum. Proc Biol Sci 283(1826):20153038

55 Fowkes FJ, Boeuf P, Beeson JGJP (2016) Immunity to malaria in an era of declining malaria transmission. Parasitology 143(2):139-153. https://doi.org/10.1017/S0031182015001249

56. Ataíde R, Powell R, Moore K, McLean A, Phyo AP, Nair S, White M, Anderson TJ, Beeson JG, Simpson JA et al (2017) Declining transmission and immunity to malaria and emerging artemisinin resistance in Thailand: a longitudinal study. J Infect Dis 216(6):723-731. https://doi.org/10.1093/infdis/jix1371

57. Raman J, Barnes KI, Baker L, Blaylock M, Blumberg L, Frean J, Misiani E, Ukpe IS (2020) Maintaining focus on administering effective malaria treatment during the COVID-19 pandemic. S Afr Med J 111(1):13-16. https://doi.org/10.7196/SAMJ.2020.v111i 11.15289

58. WHO (2011) Global Fund Malaria Proposal Development: WHO Policy Brief - WHO/GMP. World Health Organization. https:// www.who.int/malaria/publications/atoz/malaria_gf_proposal_ who_policy_fr.pdf . Accessed May 7, 2021

59. Elfawal MA (2014) Dried whole plant Artemisia annua as a novel antimalarial therapy. Dr Diss. https://doi.org/10.7275/6028909.0

60 Khan SM, Page S, Ahmad H, Harper D (2013) Identifying plant species and communities across environmental gradients in the Western Himalayas: Method development and conservation use. Ecol Inform 14:99-103. https://doi.org/10.1016/j.ecoinf.2012.11. 010

61. Isah T (2019) Stress and defense responses in plant secondary metabolites production. Biol Res 52:39. https://doi.org/10.1186/ s40659-019-0246-3

62. Finnan D (2020) Artemisia: Madagascar's Coronavirus Cure or Covid-19 Quackery? http://www.rfi.fr/en/africa/20200505-artem isia-madagascar-s-coronavirus-cure-or-covid-20200519-quack ery-covid-organics-malaria. Accessed May 18, 2021

63. Zhou P, Yang X-L, Wang X-G, Hu B, Zhang L, Zhang W, Si H-R, Zhu Y, Li B, Huang C-L et al (2020) A pneumonia outbreak associated with a new coronavirus of probable bat origin. Nature 579(7798):270-273

64. Fuzimoto AD (2021) An overview of the anti-SARS-CoV-2 properties of Artemisia anпиа, its antiviral action, protein-associated mechanisms, and repurposing for COVID-19 treatment. J Integr Med 19(5):375-388. https://doi.org/10.1016/j.joim.2021.07.003

65. Krishna S, Augustin Y, Wang J, Xu C, Staines HM, Platteeuw H, Kamarulzaman A, Sall A, Kremsner P (2020) Repurposing antimalarials to tackle the COVID-19 pandemic. Trends Parasitol 37(1):8-11. https://doi.org/10.1016/j.pt.2020.10.003

66. Global Fund (2020) Mitigating the impact of COVID-19 in countries affected by HIV, tuberculosis, and malaria. The Global Fund to Fight AIDS, Tuberculosis and Malaria. https://www.theglobalf und.org/fr/covid-19-plan/. Accessed May 15, 2021

67. WHO (2012) WHO Position Statement: Effectiveness of NonPharmaceutical Forms of Artemisia Annua Against Malaria. Geneva: World Health Organization. https://www.who.int/malar ia/position_statement_herbal_remedy_artemisia_annua_l.pdf. Accessed May 5, 2021

68. WHO (2021) WHO supports scientifically-proven traditional medicine. https://www.afro.who.int/news/who-supports-scientific ally-proven-traditional-medicine $?$ gclid $=$ Cj0KCQjwtMCKBhD AARIsAG-2Eu8R-nmBrnzewl12uygbtpgouFYKHVZXj19zeIdk 17CSVRHJn-17a11Fw16QaArtREALw_wcB. Acceced, 26th september 2021

69. Kapepula PM, Kabengele JK, Kingombe M, Van Bambeke F, Tulkens PM, Sadiki Kishabongo A, Decloedt E, Zumla A, Tiberi S, Suleman F et al (2020) Artemisia Spp. derivatives for COVID19 treatment: anecdotal use, political hype, treatment potential, challenges, and road map to randomized clinical trials. Am J Trop Med Hyg 103(3):960-964. https://doi.org/10.4269/ajtmh.20-0820

70. Witkowski B, Amaratunga C, Khim N, Sreng S, Chim P, Kim S, Lim P, Mao S, Sopha C, Sam B et al (2013) Novel phenotypic assays for the detection of artemisinin-resistant Plasmodium falciparum malaria in Cambodia: in-vitro and ex-vivo drug-response studies. Lancet Infect Dis 13(12):1043-1049

71. Mok S, Ashley EA, Ferreira PE, Zhu L, Lin Z, Yeo T, Chotivanich K, Imwong M, Pukrittayakamee S, Dhorda M et al (2015) Drug resistance. Population transcriptomics of human malaria parasites reveals the mechanism of artemisinin resistance. Science 347(6220):431-435. https://doi.org/10.1126/science.12604 03

72. Suresh N, Haldar K (2018) Mechanisms of artemisinin resistance in Plasmodium falciparum malaria. Curr Opin Pharmacol 42:46-54. https://doi.org/10.1016/j.coph.2018.1006.1003

73. Bhattacharjee S, Coppens I, Mbengue A, Suresh N, Ghorbal M, Slouka Z, Safeukui I, Tang HY, Speicher DW, Stahelin RV et al (2018) Remodeling of the malaria parasite and host human red cell by vesicle amplification that induces artemisinin resistance. Blood 131(11):1234-1247

74. Sibley CH, Hyde JE, Sims PFG, Plowe CV, Kublin JG, Mberu EK (2001) Pyrimethamine-sulfadoxine resistance in Plasmodium falciparum: what next? Trends Parasitol 17:570-571

75. Picot S, Olliaro P, De Monbrison F, Bienvenu AL, Price RN, Ringwald P (2009) A systematic review and meta-analysis of evidence for correlation between molecular markers of parasite resistance and treatment outcome in falciparum malaria. Malar J 8:1-15. https://doi.org/10.1186/1475-2875-1188-1189

76. Prodines B, Dormoi J, Briolant S, Bogreau H, Rogier C (2010) La résistance aux antipaludiques. Rev Francoph Des Lab 422:51-62. https://doi.org/10.1016/S1773-35X(10)70510-4

77. Mohammadi A, Mollalo A, Bergquist R, Kiani B (2021) Measuring COVID-19 vaccination coverage: an enhanced age-adjusted two-step floating catchment area model. Infect Dis Poverty 10(1): 118

78. Estadilla CDS, Uyheng J, de Lara-Tuprio EP, Teng TR, Macalalag JMR, Estuar MRJE (2021) Impact of vaccine supplies and delays on optimal control of the COVID-19 pandemic: mapping interventions for the Philippines. Infect Dis Poverty 10(1):107

79. WHO (2014) WHO severe malaria. Trop Med Int Health 19:7-131

80. Dhochak N, Singhal T, Kabra SK, Lodha R (2020) Pathophysiology of COVID-19: why children fare better than adults? Indian J Pediatr 14:1-10. https://doi.org/10.1007/s12098-12020-03322-y

81. Kindzeka M (2021) COVID-19 Frightens Malaria Patients in Cameroon. 2020. https://www.voanews.com/science-health/covid19-frightens-malaria-patients-cameroon. Accessed November 15, 2021

Publisher's Note Springer Nature remains neutral with regard to jurisdictional claims in published maps and institutional affiliations. 